\title{
SEMANTICO-STYLISTIC PECULARITIES OF COLORS IN PHRASEOLOGICAL SYSTEM OF THE GERMAN LANGUAGE
}

Shchyhlo L.

Candidate in Philology, Associate Professor

ORCID ID 0000-0002-9441-6175

Abdullaieva A.

Student

Antipova A.

Student

Sumy State University,

2, Rymskyi-Korsakov St., Sumy, 40007, Ukraine

1.schiglo@gmail.com

The proposed study deals with color namings as a special semantico-stylistic layer of vocabulary, pecularities of their usage, explicit and implicit meanings, and their role in phraseological units. The relevance of the topic is determined by the fact that the color namings that are part of the phraseological system of the German language, often convey not a direct feature of the object, but only give an indication of the similarity with another phenomenon or object. Thus, non-vocabulary meanings of color namings are actualized in the composition of stable expressions, which allows a wider representation of the common linguistic view of the world. In addition, color namings that are components of German idioms, presetnly, are not sufficiently investigated, therefore, the direction of the work is promising.

Phraseological units accompany human life from birth to death. They give a description of the world, human activities, and the person himself. At the same time, each object of our reality is characterized by a certain color, even if it is barely noticeable and indistinct. A person perceives color not only as an objective characteristic, but also as a moral and aesthetic category. This category expresses attitude, assessment, norm. Phraseological units that have color namings in their composition are accompanied by evaluative connotations and are correlated with a holistic world view of a particular national culture.

Having obtained deep symbolic semantics in the process of the development of the German language, the colors reflect the linguistic view of the world through the prism of which native speakers perceive reality. The analysis of the material of the German language showed that the colors schwarz, weiß, rot, grün, grau, gelb, blau are the main color namings in the German language. Almost all the analyzed colors are characterized by binary meanings, which are widely represented in the linguistic view of the world of the German people by phraseological units with positive and negative connotations. The spheres of application of phraseological units with a component of color are found out: political, historical, economic, religious, spiritual, household. Color lexemes can be classified into basic (achromatic, non-achromatic) and non-basic (derived from basic colors).

Key words: phraseological unit, color naming, phraseological composition of the German language, semantic and stylistic pecularities.

Introduction. Phraseological units accompany human life from birth to death. They give a description of the world, human activities, and the person himself. At the same time, each object of our reality is characterized by a certain color, even if it is barely noticeable and indistinct. A person perceives color not only as an objective characteristic, but also as a

(C) Щигло Л. В., Абдуллаєва А. Ф., Антіпова А. Ю., 2019

moral and aesthetic category. This category expresses attitude, assessment, norm. Phraseological units that have color namings in their composition are accompanied by 
evaluative connotations and are correlated with a holistic world view of a particular national culture.

Therefore, it is not surprising that in recent years, phraseological units with color namings have attracted the attention of researchers. (O. Zubach, L. Kovbasiuk, T. Kozak, I. Humeniuk, L. Donetskykh, V. Diatchuk, L. Pustovit, T. Semashko and others). According to linguists, «phraseological units with the component «color namimg» belong to a part of the nominative composition of the language, which is characterized by a expressed cultural and national identity» [7, p. 268].

The proposed study deals with color namings as a special semantico-stylistic layer of vocabulary, pecularities of their usage, explicit and implicit meanings, and their role in phraseological units. The relevance of the topic is determined by the fact that the color namings that are part of the phraseological composition of the German language, often convey not a direct feature of the object, but only give an indication of the similarity with another phenomenon or object. Thus, non-vocabulary meanings of color namings are actualized in the composition of stable expressions, which allows a wider representation of the common linguistic view of the world. In addition, color namings that are components of German idioms, presetnly, are not sufficiently investigated, therefore, the direction of the work is promising.

Taking into account the state of the study of the color naming functional pecularities in the phraseological composition of the German language, the current tendency in the study of their semantics, the objectives of the research, on the basis of semantico-stylistic analysis, are studying out the peculiarities of color nominations as components of the phraseological units of the German language.

Achieving the objectives involves performing the following necessary tasks:

1) to analyze the directions of linguistic research in the field of phraseological unit and to identify the main pecularities of phraseological units;

2) to examine some of the classification of phraseological units;

3 ) to find out the phenomenon of color in the composition of stable expressions;

4) to determine the scope of the usagee of phraseological units with a color component;

5) to investigate the semantic features and functional load of color nominations, which are components of the phraseological units of the German language.

The subject area of the research is semantico-stylistic peculiarities of the phraseological units with color namings in the German language.

The specific topic is to describe the semantico-stylistic pecularities of color nominations as components of phraseological units.

Results of the research. The phraseological units, due to their vivid national coloring, characterizing a certain attitude to the way of life of people, a system of values, has long been the subject of discussions of linguists. For today, there is a large number of scientists, scholars who have studied the concept of «phraseological units», their features, nature, semantics, spheres of distribution, and so on. Thus, V. Vynogradov and his followers V. Arkhanhelskyi, O. M. Babkin, M. M. Shanskyi, L. I. Roizenzon, V. P. Zhukov, R. N. Popov, I. I. Chernyshov studied such cardinal problems, as the volume and subject of phraseology, features of phraseological units, peculiarities of phraseological significance, the research methodology.

The term «phraseological unit» was first approved by V. V. Vynogradov and should have been used to refer to those compounds that are formed not during the linguistic process, but are reproduced in accordance with tradition. Consequently, the reproducibility, according to the scientist, is the main feature of phraseological units [3, p. 59-62].

In linguistics there are more than 20 definitions of the concept of «phraseological unit», but it should be noted that today no one can reach the only definition of this concept.

«Phraseological unit» is:

1) a separate independent unit of speech, characterized by phraseological significance, component composition, grammatical categories, reproducibility [1, p. 16]. 
2) a separate independent unit of the language, «which is characterized by the phrasal meaning, component composition and grammatical categories, and performs a nominative function, and, with it, characterizes the subject of the phrase, or its dynamic and statistical peculiarities» $[6$, p. 240].

3 ) consists of more than one word and is a combination of words that are not connected with each other during the speech, and have long been known in the language [11, p. 11].

Phraseological units are marked by a number of characteristics that allow them to be considered independent units of the language, different from other linguistic units - from words, phrases, sentences.

Having analyzed the existing definitions of phraseological units, one can distinguish the following number of features:

1) semantic integrity or semantic instability (V. V. Vynogradov, V. L. Arkhanhelskyi, V. P. Zhukov, M. Shanskyi, L. A. Bulakhovskyi, G. Burger);

2) metaphorical (B. O. Larin, A. V. Kunin, V. P. Zhukov, A. M. Babkin);

3) apart organized (V. P. Zhukov, M. Shanskyi, S. G. Havrin, L. H. Skrypnyk);

4) reproducibility (V. V. Vynogradov, V. L. Arkhanghelskyi, M. Shanskyi, S. H. Havrin, V. P. Zhukov, L. G. Skrypnyk, G. Burger);

5) the presence of at least two full-meaning words (S. H. Havrin, M. M. Shanskyi, H. Burger);

6) untranslatability into other languages (L. A. Bulakhovskyi).

The phraseological units of the German language are varied and multifaceted classified. They are created depending on the purpose of their research, the years of phraseological studies, separate layers or considered criteria (structural, morphological-syntactic or semantic). So far, there has not been a clear classification, so we suggest you to review only a part of them at the moment.

I. In the studies of V. V. Vynohradov [4] the classification of units of phraseology according to the degree of semantic indivisibility is proposed. The linguist identified three types of phraseological units: phraseological fusions (idioms), phraseological unities, and phraseological combinations.

Phraseological fusions (starre phraseologische Verbindungen) is a completely indivisible, indecomposable stable phrase, the holistic meaning of which is not motivated, that is, it is not deduced from the meanings of its constituent components, for example: jemanden / etwas im Stich lassen; jemandem urch die Lappen gehen; Kochdampf schieben.

Phraseological unities (phraseologische Einheiten) are semantically indivisible, holistic, consistent content phrases, for example: Öl ins Feuer gießen; Stroh im Kopf haben; wie ein Buch reden. In phraseological units of this type, the general meaning can be motivated by the semantics of word-components: it is to some extent linked with the meaning of words that are part of their composition.

Phraseological combinations (einfache phraseologische Verbindungen) are stable motivated figures of speech, that is their holistic meaning comes out from the meanings of the constituent parts of their separate words, for example: Abschied nehmen; Erfolg, Interesse, Aussichten haben; zum Ausdruck bringen.

The compilers distinguish, from purely structural separation, the pair composites of the words (Zwillingsformen), which, according to the degree of adhesion and rethinking of the components, are partly referred to unities, and partly to idioms.

II. Classification of phraseological units by Wolfgang Fleischer from a morphologicallysyntactic view [12].

In the case of such a classification, parts of the language of the separate components are considered and further differentiated according to the main components:

- substantival (substantivische) - consist of a «main word» and its attributes, for example, der Bund fürs Leben;

- adjective (adjektivische) - the authors pay little attention to this category because they are not numerous, for example fix and fertig; 
- adverbial (adverbiale) - this category includes a large number of frequently used phraseological units, for example, unter vier Augen, im großen und ganze;

- verbal (verbale) - in this case, each phrase combines a verb with a predicate function. This category is the most common of all.

III. Harald Burger in his basic classification [11] distinguishes the following types of phraseologisms:

1) referential phrasalological units (Referentielle Phraseologismen) - relate to objects, processes, phenomena of reality (real or fictitious): schwarzes Brett;

2) structural phraseologiscal units (Strukturelle Phraseologismen) - establish grammatical relations: in Bezug auf;

3) communicative phraseological units (Kommunikative Phraseologismen) - have a specific task in establishing, defining, implementation and completing communicative actions. Such phraseologisms can also be called routine formulas (Routineformeln): Guten Morgen.

According to T. M. Haidukova, the color denoting lexemes can be classified into basic (achromatic, non-achromatic) and non-basic (derived from basic colors) [5, p. 12].

Akhromatic colors in the painting are those that do not have warm-cold shades, and they differ from each other only in degree of light.

In German philology, white colour semantics is associated with purity, innocence, salvation, frankness, openness, simplicity, truth: weiße Weste haben (to be innocent) [9, p. 583], ein weißes Blat Papier (blank sheet of paper) [2, p. 583], ein weißer Fleck auf der Landkarte (to be a white, undiscovered place on the map) [2, p. 583]. This color evokes a joyful, optimistic mood, symbolizing a light, cheerful beginning: eine weiße Hemdbrust (have an unblemished reputation) [9, p. 583]. This color naming usually has a positive connotation, but there are also negative meanings: cold, snow, winter, illness, hospital: er ist ganz weiß im Gesicht (to turn pale) [9, p. 583].

Black colour symbolizes darkness, sadness, hatred, death. Therefore, phraseological units with a black component have a connotation of negativity, pessimistic mood or sensation, grief, failure: etw. schwarz (schwarz in schwarz) (an) sehen / malen (to see something in a dark light), schwarz sehen (to be pessimistic; to see that things are nasty) [9, p. 182], die schwarze Kugel gezogen haben (to fail, to make a bad choice) [9, p. 413]. In addition, black color can denote humiliation, destruction, evil: $j$ - $n$ schwarz ärgern (to bring someone to misery), schwarz abgeschrieben sein bei $j-m$ (to have a bad reputation in someone) [9, p. 182]. In German, the meaning of black color was fixed in the colors of illegal, unlawful, prohibited or uncommon actions, deception, betrayal: er ist dort (im Zirkus, Theater ua) schwarz gewesen (he gatecrashed there (in a circus, a theater, etc.) he went there without a ticket) [10, p. 545], schwarz (über die Grenzen) kommen (illegally pass (border)) [9, p. 182].

Sometimes there are phraseological units without coloring (giving the subjects a clear color), only a shade that indicates whether an object, a phenomenon etc. is light or dark. As well as their colorful matches, a color naming dark (dunkel) carries a connotation of something negative, illegal, concealed: etw. vor $\mathrm{j}$-m dunkel halten (to hide something from somebody) [9, p.136]; and light (hell) means clarity, authenticity, undividedness: hell und klar sein (to be completely obvious, clear), heller Wahnsinn (real insanity), helle, da $\beta$ (mich) die Augen beißen (clear as a bell, clear as daylight) [9, p. 285].

Gray (grau) is graceful, dull, denotes monotony, spiritual and moral poverty, emptiness of life: als graue Elend kriegen (to despair), grau in grau or alles in grau sehen (in shades of gray, dimly) [9, p. 279]. Also, grau (gray) is often used to denote activitiy, straddling boundaries of something (since the gray color consists of black and white): das ist nicht grau und nicht grün (betwixt and between) [9, p. 279]. We also discovers the following idioms with this adjective in German language, which refer to gray hair, old age, antiquity, old age: alt und grau werden (to become old and gray), graue Vorzeit (or Zeit) (hoary antiquity) [9, p. 279]. 
Chromatic include all the colors of the solar spectrum: red, orange, yellow, green, blue, light-blue, purple. The primary colors of the spectrum are red, yellow, and blue.

The red color symbol is the widest [8]. Phraseologisms with a component of red may bear a connotation of a special, long-awaited event, holiday: einen Tag i Kalender rot anstreichen (especially celebrate any day) [9, p. 365]. It's our instinct to blush when we feel some emotions, such as indignation, anger, fury or shame. This is that precisely helped enhance some phraseological locutions with a component of red color: rot anlaufen (werden) (to turn red, to dip paint), $\mathrm{j}$-n rot machen (to make someone redden), es war ihm rot vor den Augen (the rage dazzled him) [10, p. 500]. In addition, the red color can be associated with money, pennies, or poverty: keinen (or nicht einen) roten Heller besitzen (to live off nothing), keinen roten Heller zahlen (not to pay not a dime) [9, p. 321].

Pink (rosa) means something secret, hidden, that came from the ancient Romans, for whom the rose was an emblem of mystery: etw. sub rosa sagen (to say something in a great secrecy) [10, p. 500].

Blue (blau) symbolizes the cloudless sky, the impossible dream, the infinity, the purity, the nobility: die blaue Blume (a blue flower, the embodiment of unfulfilled dreams), blaues Blut (blue blood, noble origin) [9, p. 106]. Besides positive, there are also negative sides: intoxication, deceit, bad content of messages or events, anger: blau machen (to shirk, to booze), blau reden ( to lie, to screw up), blau (unschuldsblau) sein (to be very drunk, to be very fool) [10, p. 87], ein blauer Brief (official written notice of dismissal or student's underachievement), blauer montag (absenteeism on Monday) [9, p. 106].

There is also ambiguous green color (grün). On the one hand, the green color is associated with nature, spring, youth, health, life, calmness, joy: noch zu grün sein für (to be too young, inexperienced) [10, p. 249], ein grüner Junge (spring chicken, sucker) [9, p. 283]; on the other hand, it is a color of jealousy, anger, irregularity: $j-n$ grün und blau schlagen (to beat someone almost to death), sich grün und gelb ärgern (angry, rage) [10, p. 249]. This color holds a connotation of arrogance, excessive self-love as well: sich grün machen (to think highly of yourself), j-m nicht grün sein (not to be admonished to anyone, to dislike someone) [9, p. 283].

It is recorded the most negative value of the yellow color (gelb) in German phraseology. It often symbolizes such human qualities as insincerity, envy, anger: Gelb und grün werden (to green with envy, anger) [10, p. 224], der gelbe Neid (green envy) [9, p. 75], sich gelb und grün ärgern (to green with anger) [9, p. 45].

Genetically related to gelb is golden color (golden), which is associated with gold, money, profit, wealth: die goldene Kalb (a symbol of wealth - a golden calf) [10, p. 364]. On the contrary, its figurative meaning symbolizes something sublime, outstanding, honorable, immaterial, spiritual values: die goldene Hochzeit (golden wedding) [10, p. 343], das goldene Buch (honorary book) [10, p. 275], goldene Worte (farewell greetings, wishes) [10, p. 327].

Brown color (braun) is rare in use in folk traditions, images, tales and folklore [5, p. 13]. This color is mainly used in the strictes sense: brauns Haar (nutbrown hair), braune Augen (brown eyes), braune haut (tanned skin) [10, p. 285]. However, brown is also associated with fascism and the Nazi: the braune Vergangenheit (Nazi past) [10, p. 285].

Conclusions. There is no single definition of the «phraseological unit» among the phraseological units researchers. By the phraseological unit one understands the lexicalgrammatical unity of two or more distinctly formed components, grammatically organized by the model of a phrase or sentence, but indivisible lexically, stable in its composition and structure, which, having integral meaning, is reproduced in the language. Among the many features of phraseological units we can single out the most general: the presence of at least two full-fledged words, semantic integrity, metaphor, stability, reproducibility, etc.

Linguists study phraseological units in various aspects and classify them according to different characteristics. There are a number of classifications of phraseological units (semantic, morphological, stylistic, structural, grammatical, genetic). Among the many classifications, the most commonly used is classification of phraseological units by degree 
of semantic indivisibility (phraseological fusions (idioms), phraseological unities, and phraseological combinations) proposed by Vinogradov V. V.

Acquiring a profound symbolic semantics in the development of the German language, the colors reflect the linguistic picture of the world, through the prism of which native speakers perceive reality. The material analysis ostended that the colors schwarz, weiß, rot, grün, grau, gelb, blau are the main color denotations in the German language. Almost all analyzed colors are characterized by the binarity of meanings, widely represented by phraseological units with a positive and negative connotation in the language picture of the world of the German people. It found out the fields of application of phraseological units with a component of color: political, historical, economic, religious, spiritual, social. Lexemes on the color scheme can be classified into basic (achromatic, non-achromatic) and non-basic (derived from the primary colors).

In the process of achromatic color denotations analysis (white, black and all the intermediate gray colors between them), it was found that they have positive and negative semantics. The color namings «black» and «gray» and «dark» in the German phraseological fund, mostly transmit a negative content. Frequently phraseological units with these color namings are used to refer to concepts of pessimistic mood, grief, despair, failure, illegal or covert actions, deception, humiliation, monotony, and destruction. The color nominations «white» and «light» projects positive meanings and elicit joyful emotions: purity, authenticity, undivided, cheerful beginning.

Chromatic colors are red (rot), yellow (gelb), green (grün), blue (blau) and their shades: golden (golden), pink (rosa) - perform the different stylistic functions as part of phraseological units. Connotation of red color is controversial. It can symbolize passion, victory, holiness, life, love, and anger, vengeance, rage or shame. The shade of red, pink, conveys the meaning of something secret, hidden. The blue color is also binary: on the one hand it is interpreted as purity, unrealistic dreams, nobility, and on the other hand - as anger, falsehood, drunkenness. To indicate the color in the phraseological composition of the German language lexemes of green and yellow hold a connotation of rage, envy and jealousy. Besides, it is associated with the physiological processes of the human body. However, these color namings also carry a positive interpretation: green symbolizes nature, youth, the birth of a new one; And, genetically related to yellow, gold is compared to something spiritual and respectful. Connotation of the brown color is rather narrow: in most cases, the color retains its direct meaning, but sometimes there are associations with fascism.

The multidimensional nature of the raised issue requires further elaboration in the following scientific studies: conducting a typology between the Ukrainian or English languages, the use of phraseological units with a color component in various spheres of human activity, various discourses, etc.

\section{СЕМАНТИКО-СТИЛІСТИЧНІ ОСОБЛИВОСТІ КОЛЬОРОНАЗВ У ФРАЗЕОЛОГІЧНІЙ СИСТЕМІ НІМЕЦЬКОЇ МОВИ}

Щигло Л. В.

Кандидат філологічних наук, доцент

ORCID ID 0000-0002-9441-6175

Абдуллаєва А. Ф.

Студентка

Антіпова А. Ю.

Студентка

Сумський державний університет

вул. Римського-Корсакова, 2, м. Суми, 40007, Україна

1.schiglo@gmail.com

Пропоноване дослідження присвячене кольороназвам як особливому семантикостилістичному шару лексики, особливостям їх вжсивання, експліщитним та імплічитним значенням, ролі у фразеологізмах. Кольоронайменування, які входять до 
складу фразеологічної системи німецької мови, частіше передають не пряму ознаку предмета, а лише дають вказівку на подібність з іншим явищем чи предметом. У складі усталених виразів актуалізуються несловникові значення кольороназв, щзо дозволяе ширше висвітлити загальномовну картину світу. Фразеологізми супроводжують людське життя від народження й до самої смерті, характеризують навколишній світ, діяльність людини та саму людину. Будь-який об'єкт нашоі дійсності описується певним кольором, навіть якщо він ледь помітний $і$ нечіткий. Людина сприймає колір не лише як об'єктивну характеристику, але й як моральноестетичну категорію. Ця категорія виражає ставлення, оцінку, норму. Фразеологічні одиниці, щуо мають у складі назви кольорів, супроводжуються оцінними конотаціями та співвіднесені з иілісною картиною світу окремої національної культури.

Набувши у процесі розвитку німецької мови глибинної символічної семантики, кольори віддзеркалюють мовну картину світу, через призму якої носії мови сприймають дійсність. Аналіз матеріалу німецької мови показав, щзо кольори schwarz, weiß, rot, grün, grau, gelb, blaи є основними кольоропозначеннями в німецькій мові. Майже всі проаналізовані кольори характеризуються бінарністю значень, які широко представлені у мовній картині світу німецького народу фразеологізмами з позитивною та негативною конотацією. 3'ясовано сфери застосування фразеологічних одиниць з компонентом кольору: політична, історична, економічна, релігійна, духовна, побутова. Фразеологічні єдності на позначення кольору можна класифікувати на основні (ахроматичні, неахроматичні) та неосновні (похідні від основних кольорів).

Ключові слова: фразеологізм, кольороназва, фразеологічний склад німечької мови, семантико-стилічтичні особливості.

\section{СЕМАНТИКО-СТИЛИСТИЧЕСКИЕ ОСОБЕННОСТИ ЦВЕТОНАИМЕНОВАНИЙ ВО ФРАЗЕОЛОГИЧЕСКОЙ СИСТЕМЕ НЕМЕЦКОГО ЯЗЫКА}

Щигло Л. В.

Кандидат филологических наук, доцент

ORCID ID 0000-0002-9441-6175

Абдуллаева А. Ф.

Студентка

Антипова А. Ю.

Студентка

Сумской государственный университет

ул. Римского-Корсакова, 2, г. Сумы, 40007, Украина

E-mail: 1.schiglo@gmail.com

Предложенное исследование посвящено ияветонаименованиям как особенному семантико-стилистическому слою лексики, особенностям их употребления, эксплицитным $и$ имплициитным значениям, роли в фразеологизмах. Цветонаименования, которые входят в состав фразеологической системы немеикого языка, чаще передают не прямой признак предмета, а лишь дают указание на сходство с другим явлением или предметом. В составе устойчивых выражений актуализируются несловарные значения ияветонаименований, что позволяет шире представить общеязыковую картину мира. Фразеологизмы сопровождают человеческую жизнь от рождения и до самой смерти, характеризуют окружаюший мир, деятельность человека и самого человека. Любой объект нашей действительности описывается определенным цветом, даже если он едва заметен и нечеткий. Человек воспринимает ивет не только как объективную характеристику, но и как морально-эстетическую категорию. Эта категория выражает отношение, оиенку, норму. Фразеологические единицы, имеющие в составе названия иявета, 
сопровождаются оценочными коннотациями и соотнесены с иелостной картиной мира отдельной национальной культуры.

Получив в проиессе развития немецккого языка глубинной символической семантики, цвета отражают языковую картину мира, через призму которой носители языка воспринимают действительность. Анализ материала немецкого языка показал, что ивета schwarz, weiß, rot, grün, grau, gelb, blaи являются основными ияветонаименованиями в немецком языке. Почти все проанализированные иявета характеризуются бинарностью значений, которые широко представлены в языковой картине мира немецкого народа фразеологизмами с положительной и отрицательной коннотацией. Выяснено сферы применения фразеологических единии с компонентом ивета: политическая, историческая, экономическая, религиозная, духовная, бытовая. Фразеологические единства для обозначения иявета можно классифицировать на основные (ахроматические, неахроматичнские) и неосновные (производные от основных ияветов).

Ключевые слова: фразеологизм, ияветонаименование, фразеологический состав немецкого языка, семантико-стиличтические особенности.

\section{СПИСОК ВИКОРИСТАНИХ ДЖЕРЕЛ}

1. Авксентьєв Л. Г. Сучасна українська мова. Фразеологія : навч. посібник. Харків: Вища шк., 1983. 137 с.

2. Большой немецко-русский словарь : В 3 т. - Т. 2 / Авт.-сост. Е. И. Лепинг, Н. П. Страхова, Н. И. Филичева и др.; Под общ. рук. О. И. Москальской. 8-е изд., стереотип. Москва : Рус. яз., 2002. 680 с.

3. Виноградов В. В. Лексикология и лексикография. Москва : Наука, 1977. 254 с.

4. Виноградов В. В. Об основных типах фразеологических единиц в русском языке. Москва, 1986. 342 с.

5. Гайдукова Т.М. Цветообразование человека и частей его тела : автореф. дис. на соискание научн. степени канд. филол. наук: «Германские языки». Нижний Новгород, 2008. 23 с.

6. Демський М. Т. Деривація фразем на базі слів та вільних синтаксичних конструкцій. Львів : Мовознавство, 1988. С. 37-45.

7. Ковбасюк Л. А. Фразеологічні одиниці 3 компонентом «кольороназва» як елементи національно-мовної картини світу (на матеріалі німецької та англійської мов) // Проблеми зіставної семантики : Вип. 7. Київ : Вид. центр КНЛУ, 2005. С. 267-273.

8. Козак Т. Б. Лексико-семантична група слів, які позначають колір у німецькій мові : автореф. дис. на здобуття наук. ступеня канд. філол. наук : спец. 10.02.04. «Германські мови». Одеса, 2002. 18 с.

9. Німецько-український фразеологічний словник / [укл. В. І. Гаврись, О. П. Пророченко] Т. 2. Київ: Рад. Школа, 1981. 382 с.

10. Осовецька Л. С. Фразеологічний словник німецької мови / Л. С. Осовецька, К. М. Сільвестрова. Киїів : Рад. школа, 1964. 716 с.

11. Burger H. Phraseologie: Eine Einführung am Beispiel des Deutschen. Berlin : Erich Schmidt Verlag, 2007. 240 S.

12. Fleischer W. Phraseologie der deutschen Gegenwartssprache. 1. Aufl. Leipzig : VEB Bibliographisches Institut, 1982. 250 S.

\section{REFERENCES}

1. Avksentyev L. G. Suchasna ukrayinska mova. Frazeologiya : navch. posibnyk. Harkiv : Visha shk., 1983. 137 s.

2. Bolshoj nemecko-russkij slovar : V 3 t. - T. 2 / Avt.-sost. E. I. Leping, N. P. Strahova, N. I. Filicheva i dr.; Pod obsh. ruk. O. I. Moskalskoj. 8-e izd., stereotip. Moskva : Rus. yaz., 2002. $680 \mathrm{~s}$.

3. Vinogradov V. V. Leksikologiya i leksikografiya. Moskva : Nauka, 1977. 254 s. 
4. Vinogradov V. V. Ob osnovnyh tipah frazeologicheskih edinic v russkom yazyke. Moskva, 1986. 342 s.

5. Gajdukova T. M. Cvetoobrazovanie cheloveka i chastej ego tela : avtoref. dis. na soiskanie nauchn. stepeni kand. filol. nauk: «Germanskie yazyki». Nizhnij Novgorod, 2008. $23 \mathrm{~s}$.

6. Demskij M. T. Derivaciya frazem na bazi sliv ta vilnyh syntaksychnyh konstrukcij. Lviv : Movoznavstvo, 1988. S. 37-45.

7. Kovbasyuk L. A. Frazeologichni odinyci z komponentom «koloronazva» yak elementy nacionalno-movnoyi kartyny svitu (na materiali nimeckoyi ta anglijskoyi mov) // Problemy zistavnoyi semantyky. Vyp. 7. Kyiv : Vyd. centr KNLU, 2005. S. 267-273.

8. Kozak T. B. Leksiko-semantichna grupa sliv, yaki poznachayut kolir u nimeckij movi : avtoref. dis. na zdobuttya nauk. stupenya kand. filol. nauk : spec. 10.02.04. «Germanski movy». Odesa, 2002. 18 s.

9. Nimecko-ukrayinskyj frazeologichnyj slovnik / [ukl. V. I. Gavris, O. P. Prorochenko] T. 2. Kyiv: Rad. Shkola, 1981. $382 \mathrm{~s}$.

10. Osovecka L. S. Frazeologichnyj slovnyk nimeckoyi movy / L. S. Osovecka, K. M. Silvestrova. Kyiv : Rad. shkola, 1964. 716 s.

11. Burger H. Phraseologie: Eine Einfuhrung am Beispiel des Deutschen. Berlin : Erich Schmidt Verlag, 2007. 240 S.

12. Fleischer W. Phraseologie der deutschen Gegenwartssprache. 1. Aufl. Leipzig : VEB Bibliographisches Institut, 1982. $250 \mathrm{~S}$.

Received: 15 May, 2019 